\title{
Exeresis of bilateral mandibular torus due to speech impairment - case report
}

\author{
Exérese do tórus mandibular billateral devido a distúrbio fonético - relato de caso \\ Exéresis de toro mandibular bilateral por alteración del habla - reporte de caso
}

Received: 11/19/2021 | Reviewed: 11/28/2021 | Accept: 11/29/2021| Published: 12/11/2021

\author{
Barbara Ribeiro Rios \\ ORCID: https://orcid.org/0000-0002-5389-5536 \\ Universidade Estadual Paulista, Brasil \\ E-mail: barbara.rios@unesp.br \\ Gustavo Antonio Correa Momesso \\ ORCID: https://orcid.org/0000-0003-4529-683X \\ Universidade Estadual Paulista, Brasil \\ E-mail: gustavomomesso@gmail.com \\ Winicius Arildo Ferreira Araújo \\ ORCID: https://orcid.org/0000-0001-5529-7778 \\ Universidade Estadual Paulista, Brasil \\ E-mail: winiciusaraujo94@gmail.com \\ Stefany Barbosa \\ ORCID: https://orcid.org/0000-0002-4190-7931 \\ Universidade Estadual Paulista, Brasil \\ E-mail: stefanybarbosa61.sb@gmail.com \\ Mirela Caroline Silva \\ ORCID: https://orcid.org/0000-0002-9455-3807 \\ Universidade Estadual Paulista, Brasil \\ E-mail: Mirela.c.silva@unesp.br \\ João Matheus Fonseca e Santos \\ ORCID: https://orcid.org/0000-0002-2021-778X \\ Universidade Estadual Paulista, Brasil \\ E-mail: João.matheus@unesp.br \\ William Phillip Pereira da Silva \\ ORCID: https://orcid.org/0000-0003-4172-7217 \\ Universidade Estadual Paulista, Brasil \\ E-mail: william_phillip@hotmail.com \\ Tiburtino José de Lima Neto \\ ORCID: https://orcid.org/0000-0002-8297-4057 \\ Universidade Estadual Paulista, Brasil \\ E-mail: Tiburtinoneto@hotmail.com \\ Anderson Maikon de Souza Santos \\ ORCID: https://orcid.org/0000-0001-9371-9417 \\ Universidade Estadual Paulista, Brasil \\ E-mail: andersonmaikon@hotmail.com \\ Glauco Issamu Miyahara \\ ORCID: https://orcid.org/0000-0002-5748-9412 \\ Universidade Estadual Paulista, Brasil \\ glauco.miyahara@unesp.br \\ Leonardo Perez Faverani \\ ORCID: https://orcid.org/0000-0003-2249-3048 \\ Universidade Estadual Paulista, Brasil \\ E-mail: Leonardo.faverani@unesp.br
}

\begin{abstract}
Mandibular torus is a slow-growing bone exostosis with well-defined borders, usually oval and bilateral in shape. Diagnosis is made through clinical and radiographic findings. Surgical removal is necessary when there is a prosthetic indication, recurrent trauma, and in rare cases, due to phonetic disorders. The interference in speech caused by the torus, is due to its size and location, which interferes with the usual positioning of the tongue, changing the articulation points, and thus making pronunciation difficult. Therefore, the aim of this study is to report a clinical case of excision of a bilateral mandibular torus due to speech impairment. A 47-year-old male patient sought dental care complaining of bone growth in the mandible. The clinical examination showed a bilateral increase in the lingual region of the mandible, which was unilobular on the right side and trilobular on the left side, measuring approximately $20 \times 20 \mathrm{~mm}$. The patient underwent a surgical procedure to remove the torus under local anesthesia. In the 7-day postoperative period, suture dehiscence was observed, as well as traumatic ulcers and pain complaints. The patient
\end{abstract}


reported that he did not pay attention to postoperative care. As a method of treatment of suture dehiscence, a metronidazole paste was used, as well as a laser therapy protocol, ensuring soft tissue healing. After complete healing, in the clinical evaluation, the patient did not present difficulties in pronunciation. Therefore, it is concluded that, although uncommon, the torus, due to its growth, can interfere with the positioning of the tongue and, consequently, with phonetics, which is a plausible indication for the surgical procedure. Once, the normal bony contours of the mandible are re-established, as well as repositioning and lingual function.

Keywords: Exostoses; Speech Disorders; Surgery, oral; Osteotomy.

\section{Resumo}

O tórus mandibular é uma exostose óssea de crescimento lento, bordas bem definidas, geralmente de formato oval e bilateral. O diagnóstico é feito por meio de achados clínicos e radiográficos. A remoção cirúrgica é necessária quando há indicação protética, traumas recorrentes, e em casos raros, por distúrbios fonéticos. A interferência na fala causada pelo tórus, se dá decorrente ao seu tamanho e localização, da qual interfere o posicionamento habitual da língua, alterando os pontos articulatórios, e com isso dificultando a pronúncia. Portanto, o objetivo deste estudo é relatar um caso clínico de exérese de um tórus mandibular bilateral devido a alteração da fala. Paciente do sexo masculino, 47 anos, procurou pelos cuidados odontológicos queixando-se de crescimento ósseo na mandíbula. No exame clínico evidenciou-se um aumento bilateral, em região lingual da mandíbula, sendo unilobular do lado direito e trilobular ao lado esquerdo, apresentando cerca de $20 \times 20 \mathrm{~mm}$. Paciente foi submetido a procedimento cirúrgico de remoção do torus sob anestesia local. No pós operatório de 7 dias, observou-se deiscência de sutura, bem como úlceras traumáticas e queixa álgica. $\mathrm{O}$ paciente relatou que não se atentou aos cuidados pós-operatórios. Como método de tratamento da deiscência de sutura, foi utilizado uma pasta de metronidazol, bem como protocolo de laserterapia, garantindo a cicatrização dos tecidos moles. Após a completa cicatrização, na avaliação clínica, o paciente não apresentava dificuldades na pronúncia. Portanto conclui-se que embora pouco comum, o tórus devido ao seu crescimento pode interferir no posicionamento da língua e consequentemente na fonética, sendo essa, uma indicação plausível para o procedimento cirúrgico. Uma vez que, os contornos ósseos normais da mandíbula são restabelecidos, bem como o reposicionamento e função lingual.

Palavras-chave: Exostoses; Distúrbios da fala; Cirurgia bucal; Osteotomia.

\section{Resumen}

El toro mandibular es una exostosis ósea de crecimiento lento con bordes bien definidos, generalmente de forma ovalada y bilateral. El diagnóstico se realiza mediante hallazgos clínicos y radiográficos. La extirpación quirúrgica es necesaria cuando existe indicación protésica, traumatismos recurrentes y, en raras ocasiones, por alteraciones fonéticas. La interferencia en el habla provocada por el toro, se debe a su tamaño y ubicación, lo que interfiere con el posicionamiento habitual de la lengua, modificando los puntos de articulación y dificultando así la pronunciación. Por tanto, el objetivo de este estudio es reportar un caso clínico de exéresis de un toro mandibular bilateral por alteración del habla. Un paciente masculino de 47 años buscó atención dental quejándose de crecimiento óseo en la mandíbula. El examen clínico mostró un aumento bilateral en la región lingual de la mandíbula, que era unilobular en el lado derecho y tri lobular en el lado izquierdo, de aproximadamente 20x20mm. El paciente se sometió a un procedimiento quirúrgico para extraer el toro con anestesia local. En el postoperatorio de 7 días se observó dehiscencia de la sutura, úlceras traumáticas y quejas de dolor. El paciente refirió que no prestó atención a los cuidados postoperatorios. Como método de tratamiento de la dehiscencia de la sutura se utilizó una pasta de metronidazol, así como un protocolo de terapia con láser, asegurando la cicatrización de los tejidos blandos. Tras la cicatrización completa, en la evaluación clínica, el paciente no presentó dificultades de pronunciación. Por tanto, se concluye que, aunque infrecuente, el toro, debido a su crecimiento, puede interferir en el posicionamiento de la lengua y, en consecuencia, en la fonética, lo que es una indicación plausible para el procedimiento quirúrgico. Una vez, se restablecen los contornos óseos normales de la mandíbula, así como el reposicionamiento y la función lingual.

Palabras clave: Exostosis; Trastornos del Habla; Cirugía Bucal; Osteotomía.

\section{Introduction}

Mandibular tori is an osseous projection (exostoses) with slow growth, usually asymptomatic and characterized as well-defined bone exostoses. It is more prevalent in men in the third decade of life.(Bertazzo-Silveira et al., 2017) The etiology is multifactorial and related to environmental, genetic factors, and masticatory hyperfunction. (Mendes da Silva et al., 2017; Mourão et al., 2019; Rodríguez-Vázquez et al., 2013; Singh, 2010; Sorrentino et al., 2019)

Clinically the mandibular tori presents as an enlarged and well-defined lesion. Usually oval, covered by a normal mucosa, and hard on palpation. The lesion is little vascularized, and common in the lingual of the premolar region. (BertazzoSilveira et al., 2017) Most patients seek treatment due to phonetics disturbances, and ulcerations to any possible trauma. 
(Kannan, 2015; Mendes da Silva et al., 2017; Sorrentino et al., 2019) Intraoral and radiographic examination are mandatory to establish the diagnosis of mandibular tori. The relationship of both methods is needed to avoid misdiagnosis. The treatment will depend on the size and site of the lesion. Lesion exeresis is the treatment of choice.(Consolaro et al., 2019)

Mandibular tori growth may lead to phonetics disturbances, due to the impairment of tongue movement. (Lúcio et al., 2013; Sorrentino et al., 2019) When something results in impairment of tongue movement or in its related structures might cause speech disturbances, due to its ability of quick change of movements and form during speech and mastication. (Mendes da Silva et al., 2017)

Therefore, the aim of this work is to present a case of oral rehabilitation, of speech disturbance caused by oversized mandibular tori, through the surgical exeresis.

\section{Case Report}

A 47-year-old male patient presented at the Oral Medicine outpatient clinic complaining of bilateral growth in the floor of the mouth, causing discomfort and frequent traumas, both during hygiene and when ingesting some types of food. The patient also complained of speech impairment in pronouncing some words. On anamnesis, the patient denied comorbidities, medication use or allergies.

Intra-oral examination significant bilateral painless masses in the lingual region of the mandible, well-defined, measuring 20x20 mm in size, hard on palpation, covered by normal mucosa were evaluated. (Figure 1) A Cone Beam computed Tomography was requested to evaluate the bone limits and extension. It revealed, on the left side, a unilobular exostosis, and trilobular exostosis on the right side, with radiopaque aspect, diagnosing the mandibular torus. (Figure 2) In surgical planning, no involvement of the mandibular exostosis with the inferior alveolar nerve was observed. Thereafter, the limits of the lobes were established for posteriorly the channels to accomplish. (Figure 3)

Figure 10 Preoperative image showing the presence of bilateral mandibular torus, being unilobular on the right side and trilobular on the left side.

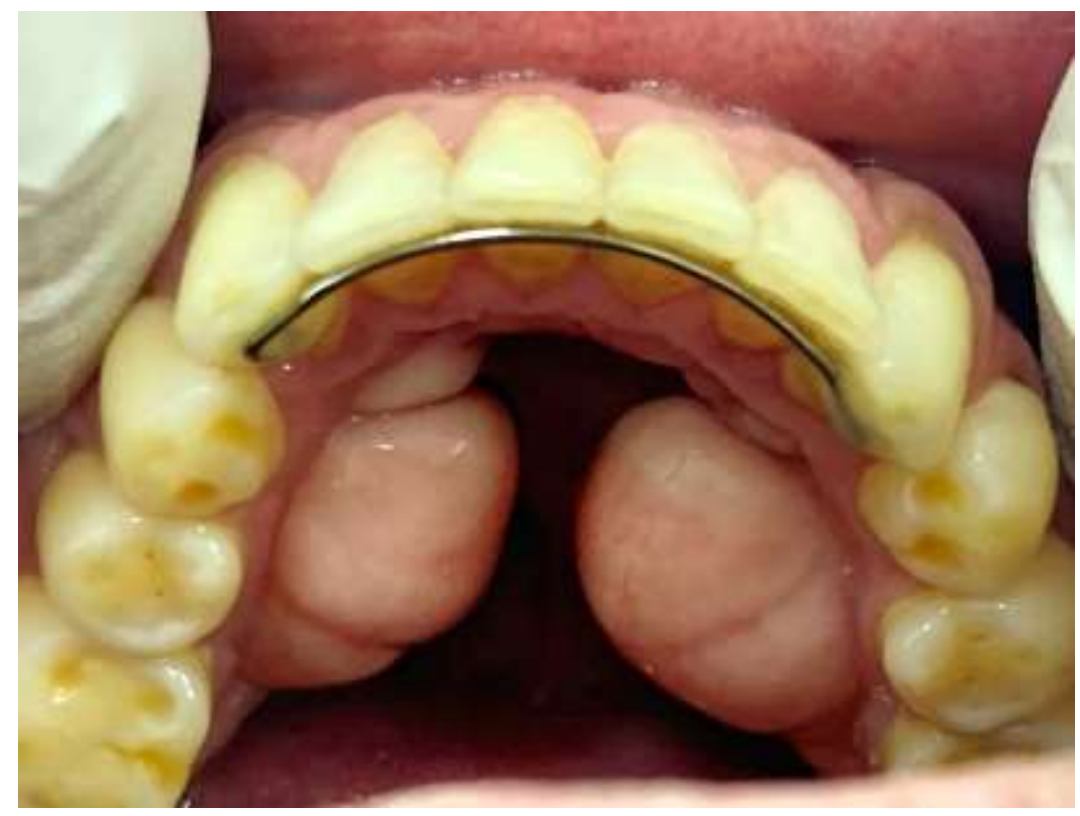

Source: Authors. 
Research, Society and Development, v. 10, n. 16, e204101623565, 2021

(CC BY 4.0) | ISSN 2525-3409 | DOI: http://dx.doi.org/10.33448/rsd-v10i16.23565

Figure 2 - Three-dimensional reconstruction and axial window computed tomography slices for hard tissue showing bilateral exostoses in the mandible.

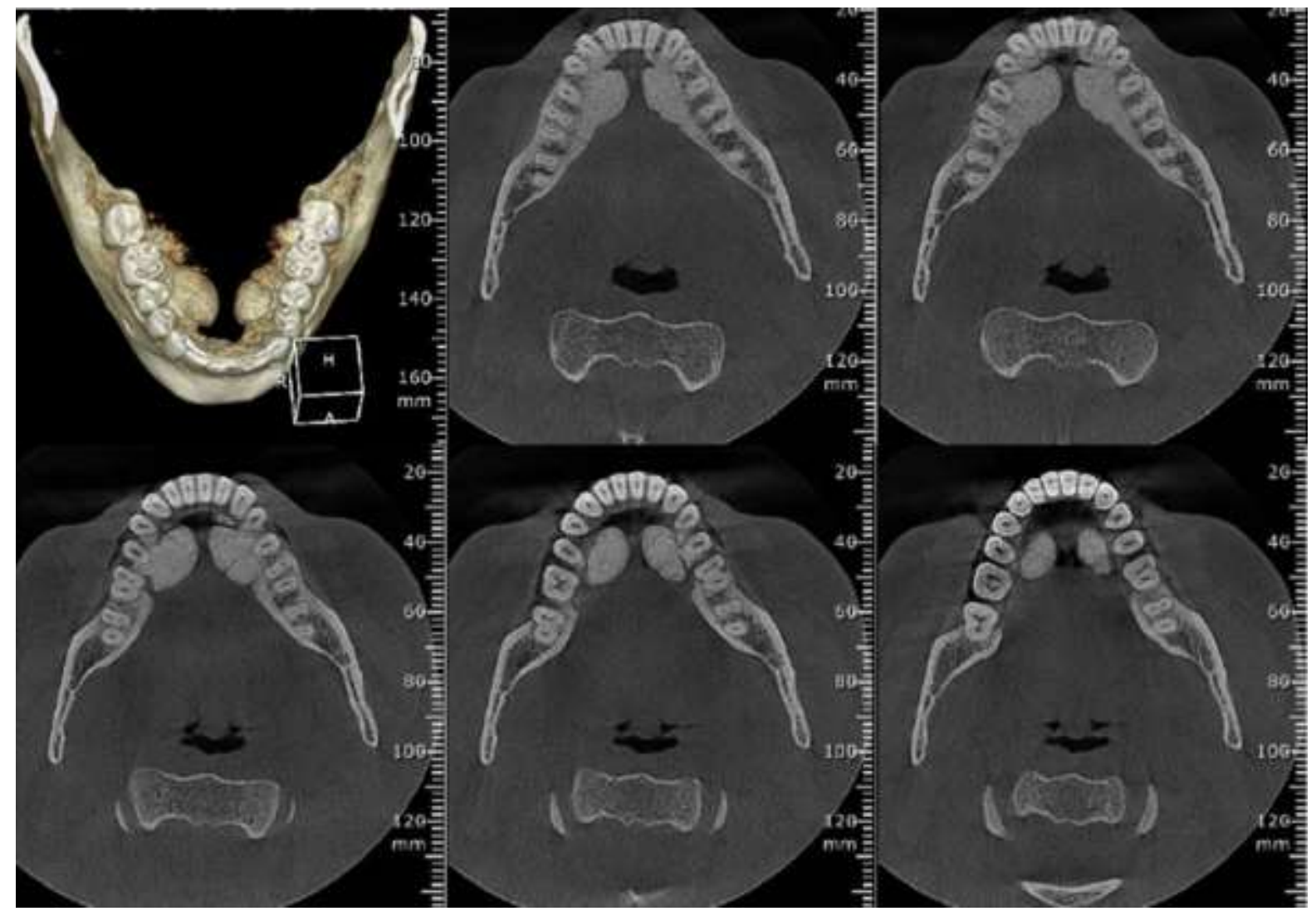

Source: Authors.

Figure 3 - Image representing the location of osteotomies performed with the aid of a 702 drill mounted at high speed, for subsequent cleavage and total exeresis and regularization of the bone bed that was previously affected by the mandibular torus.

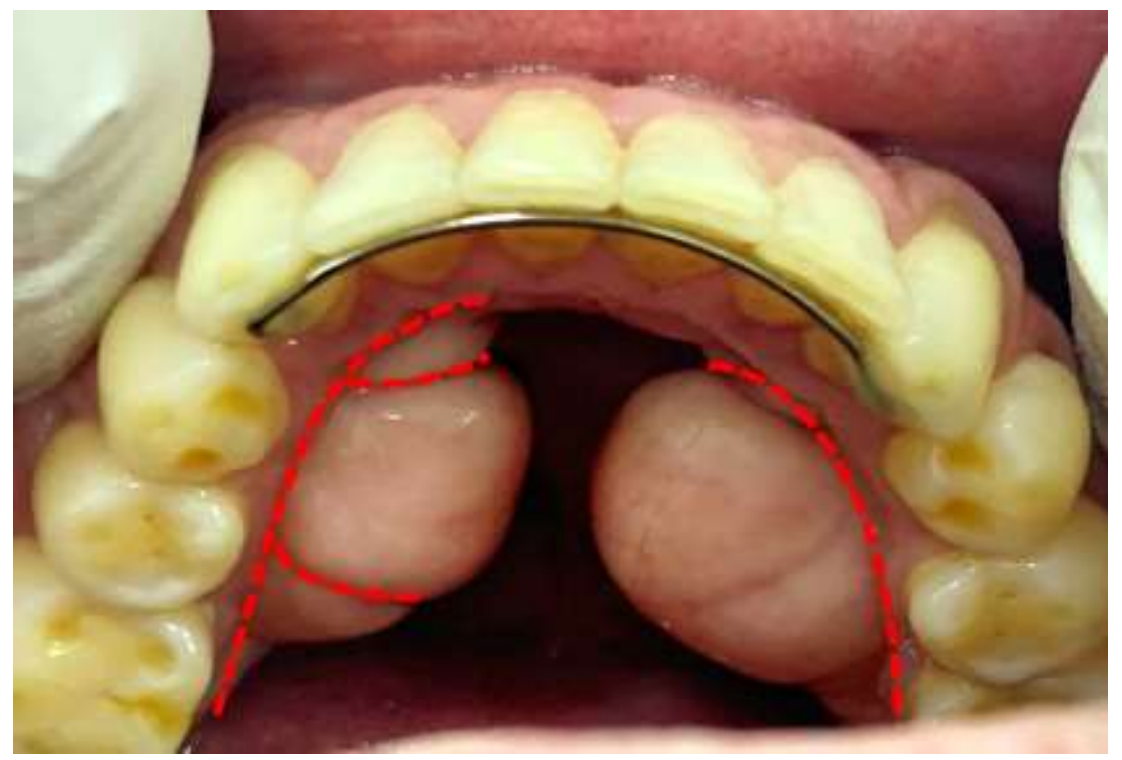


The patient had gone in speech therapist before presented to outpatient clinic, due the difficulty of pronouncing words containing the following letters: L, R, Z, S, T, D and N. Since that the mandibular tori was precluding the tongue movement, such as shortening lingual frenulum. Therefore, the mandibular tori surgery was indicated to reestablish the patient's oral phonetics

\section{Case management}

The surgical procedure was performed under local anesthesia. Intrasulcular incision and detachment from along the second molar to the lower lateral incisors, on both sides, to expose the exostosis. A channel bordering the entire length of the mandibular torus contour with the aid of a 702 drill mounted at high speed, under copious irrigation with saline solution was performed. In the right side, complemented channels in the interlobular region were performed to complete the osteotomy. Thus, with the aid of a Maxicut drill, the surgical sites were regularized under abundant irrigation avoiding sharp angles or bone spikes. Interpapillary suture was performed for re-application of the flaps with Vicryl@ 4/0. Preemptive Antibiotic and dexamethasone was administered one hour before the surgery.

In the postoperative, Amoxicillin (500mg), Dexamethasone (4mg), paracetamol (500mg)+codeine (30mg) and Chlorhexidine oral mouthwash $(0.12 \%)$ were prescribed. The surgeon highlighted the importance of liquid or pasty cold feeding and oral hygiene, such as resting period.

In the five-day follow-up, the patient showed up to the dental clinic presenting sublingual ecchymosis, compatible to the postoperative time. Although, on the 7th day after surgery, the patient returned to the dental clinic complaining of pain in the surgery region. On intraoral examination, the surgery site presented suture dehiscence with bone exposure on both sides and multiple traumatic ulcers in the mandibular mucosa. (Figure 4) The patient reported to have neglected the postoperative guidelines, ingesting hard foods and acidic liquids on the 6th day.

Figure 4 - Postoperative condition of 7 days, in which the patient presented suture dehiscence with exposure of the bone bed (regions indicated by the arrow), ulcerative wounds of traumatic origin and pain complaint after neglect of postoperative care.

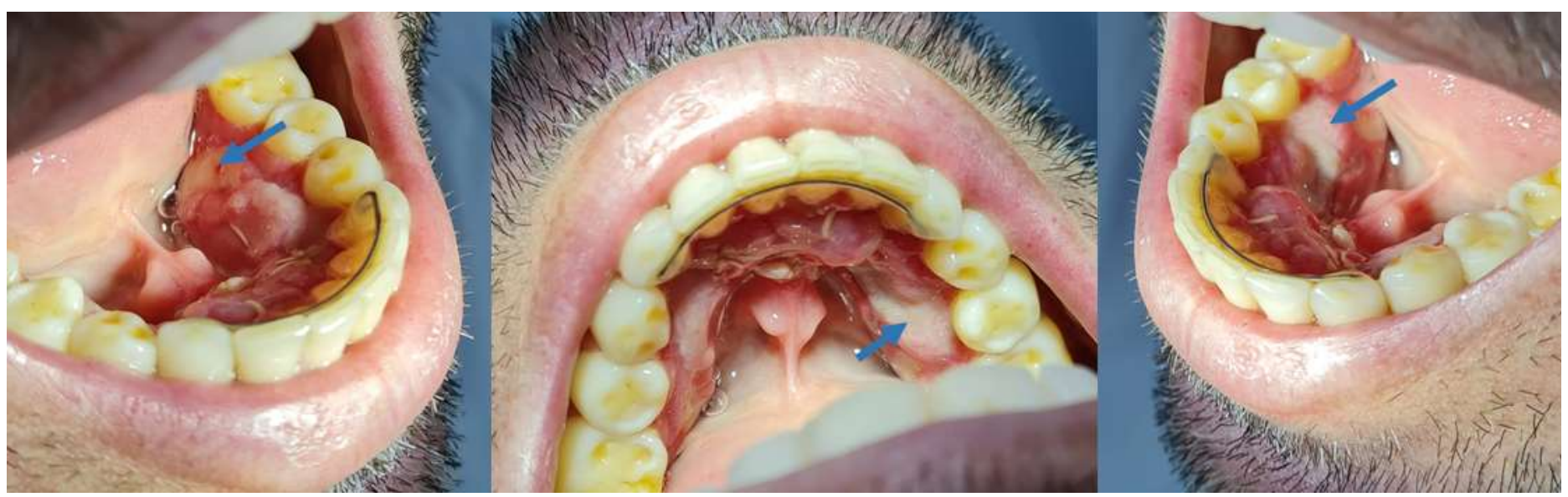

\section{Source: Authors.}

To treat the suture dehiscence was prescribed a paste composed by metronidazole (10\%), Lidocaine (2\%), mint essence $(0.5 \%)$ and Lanolin (20g) for application on dehiscence region, 3-5 times/day every day, after oral hygiene. In addition, the patient underwent intraoral laser therapy three times a week, with red light, wavelength of $660 \mathrm{~nm}$ and power of $140 \mathrm{mw}$ with $39 \mathrm{~s} /$ point in the dehiscence region for photobiomodulation in order to optimize tissue repair and wound closure. 
After 10 days, the patient presented complete closure of the dehiscence, satisfactory mandibular contour, without irregularities and with resolution of the phonetic complaint.

\section{Discussion}

Speech impediment due to mandibular tori was first described in 1954. (Springer, 1954) Since then, there were only two cases relating the interference of the tongue movement and its structures by mandibular tori. (Casenave et al., 2021; Shimahara et al., 2007) Both cases did not report which speech impairment complaint the patient had. In the present case, the patient reported difficulties to pronounce words containing the letters R, L, T, D, Z, S and N. Thus, multidisciplinary evaluation is needed for a better treatment of choice.

The production of alveolar tap can be harmed by some factors, including the frenulum shortening. The alveolar tap is of clinical interest, since the impairment of tap function would result in speech disorder, due to less amplitude of the articulators. (Camargo et al., 2013) Thus, the L, R, Z and S sound would be distorted due to the impairment function of linguo-alveolar articulatory target, and $\mathrm{T}, \mathrm{D}$, and $\mathrm{N}$ sound was distorted due to the impairment function of linguo-dental articulatory target. (Faria et al., 2019; Suzart \& Carvalho, 2016; Walsh \& McKenna Benoit, 2019)

Given the lesion features of the case presented, greater the size of the lesion, the greater the chance of harming the positioning of the tongue and the lingual frenulum.(Auškalnis et al., 2015; Casenave et al., 2021; Mourão et al., 2019; Springer, 1954) The frenulum fold the floor of the mouth and the tongue, the lingual praxis depends on its complete function. When there is something preventing its complete functioning, problems arise in the articulatory movements of the tongue and, consequently, speech problems interfere with the quality of life. (Suzart \& Carvalho, 2016)

The treatment of mandibular tori is through surgical intervention, when necessary. ((Jeff) Wang et al., 2016; García-García et al., 2010; Rastogi et al., 2013; Sorrentino et al., 2019) According to surgical management, even some authors have been suggesting the indications of general anesthesia, it was performed the local anesthesia, chosen by patient and the team. The procedure of cutting tori was performed as shown in literature. Due to the large surgery site after resection, the post operative care is needed, which was neglected by the patient. However, the suture dehiscence was seen in the follow up. The treatment of choice was the use of metronidazole paste and laser therapy, which show significant progress. (Casenave et al., 2021; Consolaro et al., 2019)

\section{Conclusion}

Mandibular tori depending on size and location can initiate different imbalances in the stomatognathic system, which is unaware by the patient until the speech impairment occurrence or diagnosed in dental routine evaluation. The main treatment in case of mandibular tori speech impairment is the excision, requiring good care by the patient due to handling the large amount of tissue and the complexity of surgical process. After removal, for oral rehabilitation, the functional aspects are resumed.

\section{Ethical approval}

Ethical approval was not applicable due to non-exposure of any information of the patient. The photos of the case report did not show facial identification or characteristics. 


\section{References}

(Jeff) Wang, C.-W., (Bruce) Huang, C.-H., Grossman, S. H., \& Pourati, J. (2016). Vertical Ridge Augmentation With Mandibular Lingual Torus Block Graft. Journal of Oral Implantology, 42(4), 369-372. https://doi.org/10.1563/aaid-joi-D-15-00151

Auškalnis, A., Bernhardt, O., Putnienè, E., Šidlauskas, A., Andriuškevičiūtė, I., \& Basevičienė, N. (2015). Oral bony outgrowths: Prevalence and genetic factor influence. Study of twins. Medicina, 51(4), 228-232. https://doi.org/10.1016/j.medici.2015.07.001

Bertazzo-Silveira, E., Stuginski-Barbosa, J., Porporatti, A. L., Dick, B., Flores-Mir, C., Manfredini, D., \& De Luca Canto, G. (2017). Association between signs and symptoms of bruxism and presence of tori: a systematic review. Clinical Oral Investigations, 21(9), 2789-2799. https://doi.org/10.1007/s00784-0172081-7

Camargo, Z. A., Marchesan, I. Q., Oliveira, L. R., Svicero, M. A. F., Pereira, L. C. K., \& Madureira, S. (2013). Lingual frenectomy and alveolar tap production: An acoustic and perceptual study. Logopedics Phoniatrics Vocology, 38(4), 157-166. https://doi.org/10.3109/14015439.2012.671357

Casenave, T., Raynaud, N., Muret, M., \& Torres, J.-H. (2021). Mandibular tori interfering with the mobility of the lingual frenulum: a short case report. Journal of Oral Medicine and Oral Surgery, 27(1), 7. https://doi.org/10.1051/mbcb/2020043

Consolaro, A., Consolaro, R. B., Hadaya, O., Oliveira, I. A. de, \& Miranda, D. A. O. (2019). Palatal and Mandibular Tori: diagnosis, clinical significance and conceptual basis. Journal of Clinical Dentistry and Research, 16(2), 134-155. https://doi.org/10.14436/2447-911x.16.2.134-155.bes

Faria, M. B. G., Da Cruz, C. D., Da Frota, R. B., Silva, C. J. P., Mesquita, R. A., Souza, L. N., Comunian, C. R., Aguiar, E. G., \& Meira, H. C. (2019). Surgical removal of giantform unilateral mandibular tori: a case report. International Journal of Oral and Maxillofacial Surgery, 48, 225. https://doi.org/10.1016/j.ijom.2019.03.691

García-García, A. S., Martínez-González, J.-M., Gómez-Font, R., Soto-Rivadeneira, A., \& Oviedo-Roldán, L. (2010). Current status of the torus palatinus and torus mandibularis. Medicina Oral, Patologia Oral y Cirugia Bucal, 15(2), e353-60. http://www.ncbi.nlm.nih.gov/pubmed/19767716

Kannan, S. (2015). Multiple bony overgrowths in the mouth - report of two cases. Clinical Cases in Mineral and Bone Metabolism. https://doi.org/10.11138/ccmbm/2015.12.3.260

Lúcio, G. de S., Perilo, T. V. de C., Vicente, L. C. C., \& Friche, A. A. de L. (2013). The impact of speech disorders quality of life: a questionnaire proposal. CoDAS, 25(6), 610-613. https://doi.org/10.1590/S2317-17822013.05000011

Mendes da Silva, J., Pérola dos Anjos Braga Pires, C., Angélica Mendes Rodrigues, L., Palinkas, M., de Luca Canto, G., Batista de Vasconcelos, P., Valéria Rancan, S., Semprini, M., Siéssere, S., \& Regalo, S. C. H. (2017). Influence of mandibular tori on stomatognathic system function. CRANIO®, 35(1), 30-37. https://doi.org/10.1080/08869634.2015.1122417

Mourão, C. F. de A. B., Mello-Machado, R. C. de, Resende, R. F. de B., Ferreira, F. S., \& Calasans-Maia, M. D. (2019). Aspectos clínicos e tomográficos de exostose mandibular extensa e o seu manejo para melhora na qualidade de vida: relato de um caso incomum na literatura. ARCHIVES OF HEALTH INVESTIGATION, 8(4). https://doi.org/10.21270/archi.v8i4.3198

Rastogi, K., Verma, S. K., \& Bhushan, R. (2013). Surgical removal of mandibular tori and its use as an autogenous graft. Case Reports, 2013(apr18 1), bcr2012008297-bcr2012008297. https://doi.org/10.1136/bcr-2012-008297

Rodríguez-Vázquez, J. F., Sakiyama, K., Verdugo-López, S., Amano, O., Murakami, G., \& Abe, S. (2013). Origin of the torus mandibularis: An embryological hypothesis. Clinical Anatomy, 26(8), 944-952. https://doi.org/10.1002/ca.22275

Singh, G. D. (2010). On the Etiology and Significance of Palatal and Mandibular Tori. CRANIO®, 28(4), 213-215. https://doi.org/10.1179/crn.2010.030 Sorrentino, Lombardi, Battilana, Decani, Henin, \& Rossi. (2019). Treatment of Symptomatic Mandibular Tori: A Case Report. Proceedings, 35(1), 75. https://doi.org/10.3390/proceedings2019035075

Springer, J. (1954). Tori mandibulari with speech impediment. Oral Surgery, Oral Medicine, Oral Pathology, 7(12), 1270-1272. https://doi.org/10.1016/00304220(54)90274-1

Suzart, D. D., \& Carvalho, A. R. R. de. (2016). Alterações de fala relacionadas às alterações do frênulo lingual em escolares. Revista CEFAC, 18(6), 13321339. https://doi.org/10.1590/1982-0216201618621715

Walsh, J., \& McKenna Benoit, M. (2019). Ankyloglossia and Other Oral Ties. Otolaryngologic Clinics of North America, 52(5), 795-811. https://doi.org/10.1016/j.otc.2019.06.008

Shimahara, T., Ariyoshi, Y., Nakajima, Y., Shimahara, M., Kurisu, Y., \& Tsuji, M. (2007). Mandibular torus with tongue movement disorder: a case report. Bull Osaka Med Col, 53, 143-6. 